\title{
Strategic Thought and Security Preoccupations in Australia
}

\author{
Coral Bell
}

This essay was previously published in the 40th anniversary edition. It is reprinted here in its near original format.

The other authors in this volume have provided such authoritative accounts of the processes that led to the foundation, 40 years ago, of the Strategic and Defence Studies Centre (SDSC), and its development since, that there is nothing that I can add on that score. Instead, this essay is devoted to exploring what might be called Australia's strategic culture: the set of intellectual and political assumptions that led to our security anxieties and strategic dilemmas having been perceived and defined as they have been. There will also be some consideration of the outside influences on perceptions in Australia, and of such 'side streams' of thought as have run somewhat counter to the mainstream, but have been represented within SDSC.

Long before Australians constituted themselves as a nation, they developed a strong sense of their potential insecurity, and the inkling of a strategy to cope with that problem. That strategy was what Australia's most powerful and influential prime minister, Robert Menzies, was (much later) to call the cultivation of 'great and powerful friends'. Initially that assumption was so automatic as hardly needing to be defined. Britain was the most powerful of the dominant players 
in world politics for almost all the 19th century, and Australia was its colony. The ascendancy of the Royal Navy in the sea lines between them provided adequate protection, and Australia's role was merely to provide expeditionary forces (starting with the Sudan War of 1885) for the campaigns in which they might be strategically useful. That tradition has remained the most regular of uses for Australia's armed forces - right up to Iraq and Afghanistan in 2006. Only the identity of the great and powerful friend has changed since 1941.

That change in strategic dependency, from the United Kingdom to the United States, was signalled as a future prospect from early in the 20th century, with the resentment and alarm that the AngloJapanese Treaty of 1902 induced in Australia. It was taken by some local observers, quite accurately, to mean that British naval power no longer stretched as far as the Pacific. That was one of the 'subtexts' to the enthusiasm with which the visit of US President Teddy Roosevelt's 'Great White Fleet' was greeted in 1908. It had some embarrassing overtones. Here is a Labor member of parliament, Arthur Griffith, on the occasion:

A great Anglo-Saxon democracy, Britain's eldest-born daughter, and the wealthiest and most advanced nation in the world, the United States ... has flung down the gauntlet to the Mongol and challenged the naval supremacy of Japan, and by its visit to Australia has given notice to the yellow races that they will have to stop in Asia. ${ }^{1}$

People were not at all coy about racist sentiments in those days.

Despite the prevalence of that type of attitude in 1908, things did not go particularly well between the United States and Australia for most of the next three decades. Australians were disappointed at the delay until 1917 of US entry into World War I. Then, at the postwar talks at Versailles in 1919, Australian Prime Minister William (Billy) Hughes emerged, rather gleefully, as one of the most irritating thorns in US President Woodrow Wilson's side, chiefly over the disposal of the German colony in New Guinea. Hughes obviously enjoyed the role:

1 Cited in Coral Bell, Dependent Ally: A Study in Australian Foreign Policy, 3rd edn (Sydney: Allen \& Unwin, in association with Department of International Relations, ANU, Canberra, 1988), p. 9. See chapters 1 and 2 for a fuller account of this early period. 
'Mr. Hughes, am I to understand that if the whole world asks Australia to agree to a mandate in respect of these islands, Australia is prepared still to defy the appeal of the whole civilized world?' 'That's about the size of it, President Wilson' replied Hughes, as he moved his ear-trumpet close to the president. ${ }^{2}$

Later, in the 1920s, there was much Australian irritation at US policy at the Washington Naval Conference (November 1921 - February 1922), and a tendency in Australia to blame the United States for the great Wall Street crash of 1929, and the subsequent depression, which hit Australia particularly hard. Throughout the 1930s, as now, irritation in rural Australia at what seemed to our farmers to be unduly protectionist US policies that kept us out of profitable markets was always a factor. It was therefore not until the approach of war became visible in 1939, and Japan had allied itself with Germany and Italy, that the 'look to America' enthusiasm of 1908 re-emerged in Canberra, and indeed not until the fall of Singapore that it became explicit it was officially asserted in Prime Minister John Curtin's well-known newspaper article and radio talk at the end of 1941. Neither UK Prime Minister Winston Churchill nor Roosevelt liked those statements, believing the publicity to be alarmist and damaging, but there was obviously no reversing the change given Australia's strategic circumstances at the time.

The six months between Pearl Harbor and the US victory in the naval battle of the Coral Sea in May 1942 seem to me undoubtedly the crucial formative period of Australian strategic thinking ever since, establishing the view that the sea-air gap round Australia was our basic zone of defence of the homeland, and that advanced air and naval capacity was the key to our chances of prevailing there, since the adversary would be almost certain to command more manpower. How that conviction is to be reconciled with the older tradition of an expeditionary force serving with larger allied contingents on distant battlefields, like Iraq and Afghanistan, is still capable of evoking passionate argument between strategists in 2006.

The World War II experience also brought some understanding, at least at the policymaking level, of one of the endemic problems of small and middle powers: that the strategic priorities of one's great 
and powerful friends may not be identical with one's own. Britain and the United States were wedded, both before and after Japan struck at Pearl Harbor, to the strategic resolution expressed in the phrase 'Beat Hitler First'. As grand strategy for the overall conduct of the war, that was difficult to quarrel with, but in terms of, for instance, the availability of aircraft to the Pacific theatre as against the Middle East, the consequences were often hard to take in Canberra. Labor's External Affairs minister, H.V. Evatt, spent most of the war making himself disliked in both Washington and London by his constant demands for various kinds of strategic assets or priorities.

The other main strategic dilemma made apparent to Canberra during the later stages of the war in the Pacific arose from Curtin's initial decision to hand over the deployment of Australian troops completely to General Douglas MacArthur. Many people later resented their use in campaigns that cost Australian lives without contributing significantly to the defeat of Japan, which was achieved essentially by US air and naval power, the island-hopping campaign across the North Pacific, and finally the atom bombs. The Curtin Government of 1942 contained no one with experience of command in war, so the initial decision was probably inevitable. Yet, by $1944-45$, some modification of that situation could have been sought; or at least some of the 'top brass' in Australia thought so. However, Curtin, by that time, was moving into a sort of twilight of final illness, Ben Chifley was not yet in charge and Frank Forde and Evatt were busy elsewhere. Thus, nothing was done, and some Australians became rather disillusioned not only about MacArthur but about the US connection in general. Perhaps that is why there was a half turn away from the United States and back towards Britain in the immediate postwar period, although Evatt continued to work (hard but unsuccessfully) at extracting a security treaty from Washington.

It was not a good time for that endeavour, nor was Evatt the right person to be making it. The secretary of state, and his policy advisers, along with the armed forces chiefs of staff, were fully absorbed, from March 1946 to June 1950, in building a line of 'containment' in Europe against the further extension westward of Soviet power. The North Atlantic Treaty Organization (NATO) Treaty, which embodied that effort, did not come into force until 1949. China by then had almost fallen to Mao Tse-tung's soldiers, but the south-west Pacific was about the last place on earth in which the United States had any reason to 
expect a strategic challenge. Besides, Evatt himself was rather 'persona non grata' in Washington. As early as 1944, the Venona decrypts ${ }^{3}$ had implicated 'sources close to the Minister' in the leak of information from Canberra to Moscow, and thence to Tokyo.

The advent of the government of Robert Menzies at the end of 1949 removed that particular obstacle, but it was only the outbreak of the Korean War in June 1950 that transformed Washington's strategic stance in the region. In effect, the sudden urgent US need for a peace treaty and continuing security relationship with Japan temporarily endowed Australian policymakers with enough diplomatic clout to enable Percy Spender, the new External Affairs minister, to negotiate the ANZUS Treaty in 1951.

Washington needed Canberra to agree to peace terms with Japan that were considerably less onerous than those originally desired by Australia. At the time, and for most of the following decade, the possibility of a revival of Japanese militarism was a more vivid preoccupation in many Australian minds than the implications of Mao Tse-tung's victory in China. By the early 1960s, however, Menzies found it politically useful to foster an alarming vision of 'Asian communism' as a dagger pointed directly at Australia's heart. After the treaty was signed, Spender became, of his own choice, ambassador in Washington, where he spent much time trying to persuade the Americans to turn ANZUS into something more like a Pacific version of NATO. He was, of course, not successful in this endeavour, with the Americans judging quite rightly that China's neighbours, then as now, were not yet ready to be recruited into the sort of containment strategy that had worked in Europe. Moreover, they also knew, since they were still reading Moscow's diplomatic traffic, that it was Joseph Stalin, rather than Mao Tse-tung, who had encouraged North Korea's bid to take over the south.

The United States therefore interpreted the outbreak of war in Korea as Stalin becoming more adventurous in his world strategy after having acquired atomic weapons in 1949. That was one reason why strategic

3 Venona was the codename for a remarkable long-term US success in breaking the Soviet diplomatic cipher system. It began as early as 1943, but was not officially acknowledged to exist until 1995. See Desmond Ball \& David Horner, Breaking the Codes: The KGB's Network in Australia, 1944-1950 (Sydney: Allen \& Unwin, 1998), for a full account, with special relevance to Australia. 
calculations at the highest official level in Europe and Washington were so extremely pessimistic — not to say alarmist — in the early 1950s. Menzies himself was once reported to have believed that the outbreak of a new world war might come as soon as 1954. Eminent strategists, like General Sir John Hackett, the commander of the British Army of the Rhine, were saying (at least privately) that such a war might mean hundreds of millions dead, mostly in Europe, in the first few days. Many analysts held that atomic or nuclear weapons might spread to as many as 40 countries in a decade or two.

That level of strategic anxiety formed the background to the beginnings of the kind of intellectual evolution of which the history of SDSC is a notable part. I had the good fortune to know some of the founding fathers of this enterprise in London and Canberra quite well - and a few of those in the United States. In my judgement, almost all of them were moved by three common convictions: that war had acquired a new dimension of lethality; that it was far too serious a matter to leave to the generals; and that it deserved a wider level of intellectual enquiry.

Probably the most important influence on academics in Australia at this time was that of their colleagues overseas - especially the influence of those in London concerned with what eventually became the International Institute for Strategic Studies (IISS). I was in London at the time, enrolled in the graduate school at the London School of Economics (LSE), but earning a crust at Chatham House, as rapporteur of a book on Britain and the United Nations (UN). Denis Healey, Michael Howard and Alastair Buchan (three of the most influential 'founding fathers' of IISS) were members of the study group for the book, so I got to know them quite well. All three, as young officers, had been through very hard wars. Healey had been 'beach master' at Anzio (one of the bloodiest landings under German fire of the entire war), Howard had fought through Germany with the Coldstreams, and Buchan, who had been in the Arnhem disaster, once told me that he had seen most of his friends die around him. It was therefore not surprising that all three believed in intellectual effort towards more rational strategies.

The project for an institute more specifically oriented to strategic issues than Chatham House and its overseas affiliates was already being considered - somewhat to the alarm of those in charge at Chatham 
House. Yet, in its earliest days as the Institute for Strategic Studies (ISS), it was a small operation, with a director and his secretary, and a couple of rooms in the Adelphi Terrace (where J.M. Barrie used to live). We used to meet over austere luncheons (a sandwich and a glass of wine), yet those were some of the best and frankest seminars I have ever attended. The Whitehall mandarins used to drift up from the Foreign Office, some journalists would drift down from Fleet Street, some colleagues and myself from LSE, and Michael Cook from Australia House. Bill Fox, head of the Institute of War and Peace Studies at Columbia University, was also there at the time, and once told me that the patronage of President Dwight Eisenhower was vital to the rise of such studies at Columbia and elsewhere in the United States. Occasionally, Thomas Schelling, who was to become perhaps the most influential theorist for part of the general enquiry into crises and conflicts, was also in attendance.

Hedley Bull came down from Oxford to teach at LSE just after this period. Though his main interest was always in international theory, his first book, The Control of the Arms Race (1961), was in the strategic area, and impressed official opinion so much that he was invited by Harold Wilson (who had just become Labour prime minister, after many years of Conservative dominance) to turn his attention to this subject at the Foreign Office. I was a member of the Advisory Board on Arms Control established by Bull, and attended some of its meetings. Very fascinating they were too, despite the sombre subject matter. Bull had a wonderful knack of getting people from a range of fields to see the relevance of their particular expertise to the possibilities of arms control. So zoologists and seismologists and physicists, as well as international relations people and politicians and diplomats, attended the meetings. I well remember a passionate argument at one of them with the eminent zoologist Lord Walter Rothschild about whether any lessons could be learned from animals on the defence of territory, and other arguments with Patrick Blackett, the equally eminent but very left-wing physicist, about the interpretation of Soviet policy, which most of us thought was pretty threatening at the time. Yet Moscow still had many friends (and some covert allies) in Labour and far-left opinion in Britain. Wilson, and later James Callaghan, as the chief decision-makers for the two Labour governments of the 1960s, had to try to reconcile left-Labour opinion to a policy that was actually of close collaboration with NATO and the United States. One of the 
ways they accomplished this was by stressing the new initiatives on arms control being evolved at the Foreign Office, with Bull's help. That strategy was later adopted in Canberra, I think, when the then foreign minister (later Governor-General) Bill Hayden faced a similar problem with Labor-left members of the parliamentary party unhappy with the ANZUS connection, just after the Vietnam War. So there is no doubt that Bull had an impact on the formation of official policy, at least while the Labour Party in Britain was in office, and perhaps also in Washington a bit later when Henry Kissinger was in office as secretary of state and the Strategic Arms Reduction Treaty (START) talks were under consideration. I think Bull knew Kissinger quite well - probably from Bull's days at the Foreign Office.

Originally most of the scenarios we contemplated at ISS concerned Europe, but from the mid-1950s we also looked at Middle Eastern problems, especially after the crises in Iran in 1953, and the Suez crisis in 1956. By the early 1960s, we were also becoming preoccupied with those in South-East Asia. In 1967, I wrote for Buchan what I think was the first of the IISS Adelphi papers on the balance (or potential balance) of power in Asia, concluding that its time had not yet arrived. Only very recently, with the rise and rise of China, has the time of a possible future Asian balancer seemed near.

The 1963 IISS conference, held at Pasadena with the help of the RAND Corporation, was, however, almost entirely devoted to the rising crisis over Vietnam, and the question of whether the United States should embark on open combat intervention, as against the covert assistance already being provided to the South Vietnamese. Conferences were very small in those days, with only 29 attending that conference (including five Australians). Buchan always said that we were destined to assume a leading role in international issues in this part of the world. We had various eminent Washington insiders from the administration of President John F. Kennedy talk to us, and they all maintained that the US president, though under heavy pressure, remained determined to avoid sending in combat troops. (That was in August, only three months before Kennedy's assassination in Dallas on 22 November 1963.) The new president, Lyndon B. Johnson, did, of course, yield to that pressure about a year later, after the alleged Gulf of Tonkin incident. I have always wondered whether, if not for Lee Harvey Oswald, the United States and Australia might perhaps have avoided that disastrous battlefield. 
Such a possibility would not have been welcome in Canberra at the time. Opinion close to the decision-making level had, for a couple of years, been far more hawkish on Vietnam than official opinion in Washington. Many people took seriously the notion of a 'BeijingJakarta Axis'; that is, a sort of revolutionary alliance between the PKI (Communist Party) in Indonesia and the Maoists in China to evict what were called the 'old established forces' (i.e. the Western powers) from this part of the world in favour of 'the new emerging forces' (i.e. the rising tide of left-nationalist insurgency). Such an axis was easy to believe at the time, with Indonesian President Sukarno practising 'Konfrontasi' against the British, Ho Chi Minh looking ever more likely to win in Vietnam, and Maoism at the peak of its ideological attraction. But by 1965, of course, Sukarno was out of power and the United States was heavily involved in South-East Asia for the next decade. Moreover, by 1969, Moscow and Beijing were quarrelling, Kissinger was starting work on his détente strategy, and the balance of forces in the world was beginning to change.

As far as atomic or nuclear weapons were concerned, the late 1960s is the period when the notion of Australia turning to them for defensive purposes lost the appeal it once had for a few policymakers and others. Australians had been involved in the research at Cambridge and elsewhere (long before Hiroshima) that led in time to the Manhattan Project, through various scientists, especially Mark Oliphant. A school of nuclear research had been established at The Australian National University (ANU), and Australia had plenty of uranium. So for some years the project seemed quite feasible. However, after the time of John Gorton as prime minister in the late 1960s (he was a fervent Australian nationalist and rather distrustful of our 'great and powerful friends'), strategic opinion turned firmly against it, despite some highlevel lobbying by a few influential insiders. The idea was certainly dead by 1970, as much for cost considerations as from a preference for reliance on the US nuclear umbrella. I believe some academic theorists (both in Australia and at IISS) had a good deal to do with that change of opinion - not perhaps directly, but because they created a climate of opinion that gradually diffused into policymaking and made much clearer (than originally) the dangers and disadvantages of 'going the nuclear route'. 
Since 1966, SDSC has been a regular forum for non-official strategic debate in Australia, but I might venture a few words about some scholars in the field who were somewhat outside the mainstream, for one reason or another. Arthur Burns, who held a chair of political science at ANU, was an early entrant into this sphere of enquiry. He published an influential monograph, From Balance to Deterrence: A Theoretical Analysis, in 1956, and a more substantial work, Of Powers and Their Politics: A Critique of Theoretical Approaches, in 1968. He was a lively and original thinker, who had some input into the foundation of SDSC, and was more at home with mathematical models than most Australians in the field. Some of the insights on the control of conflict have come from scholars associated with peace research rather than with directly strategic issues - notably professors Andrew Mack and Ramesh Thakur on the now influential concept of 'human security' as against 'national security'. A small countercurrent to mainstream strategic analysis, sceptical or distrustful of conventional official assumptions, has tended to suggest alternative modes of meeting security dilemmas, or has even denied their existence. Their influence has waxed and waned in accordance with international events. They were rather influential after the final collapse in Vietnam, and might be again if things deteriorate after the Western pull-out in Iraq (if, for instance, the situation there resembles endemic civil war rather than a budding democracy).

One prospective strategic dilemma (which has perhaps loomed larger in public opinion than among policymakers or their advisers) is whether Australia's status as a close ally of the United States seriously damages its standing among regional neighbours, who are usually disapproving of US policies - especially in the non-West. Does, in effect, current US unpopularity with world opinion rub off on Australia as a regional power, which is conscious these days of its present and future need to get on satisfactorily with the Asian governments - governments that, in turn, are increasingly anxious to promote and define a regional identity?

The answer must I think be formulated on two levels. Firstly, at the level of top official decision-makers and their advisers in our region, the climate of intellectual opinion seems tough-minded and realistic. They are fully conscious of the rise and rise of Chinese power, and know that they must live with it and make their own policies accordingly. Yet they are also conscious that it may be useful to have 
a global balance of power that will act as a restraining factor on future ambitions that might prove damaging to their own interests. They are therefore not necessarily anxious to see US power opt out of East Asia, and they are fully conscious that Australian security ties are one of the factors keeping Washington interested in this part of the world. So, on the whole, at that level, the alliance may be an asset rather than a hindrance, even though political leaders (like Malaysia's Mahathir Mohamad) have found it a politically useful stick to beat Australia with.

A more complex issue is often present in these calculations: the status of Taiwan. Canberra stands firmly with the United States on its longestablished 'one China' policy; that is, the status quo needs to be maintained by both sides. (No unilateral declaration of independence by Taiwan: no military attack from the mainland.) But if the efforts to prevent matters coming to a crisis fail, and the United States should become involved in hostilities over Taiwan, I have heard Canberra's attitude defined to the United States in somewhat cryptic terms as 'we will go up the hill with you, but we will not jump over the precipice with you'. No doubt the circumstances of the time would determine the issue, but a carefully ambiguous signal is often useful in diplomacy. On the whole, the kind of public apprehension often raised in Australia about the US alliance damaging our relations with regional powers seems to me unjustified, especially with regard to China, whose own diplomacy worldwide is impressively sophisticated.

Finally, it might be asked whether the factors that have shaped Australia's strategic culture in the past several decades will be equally influential in the next few. One established factor will, to my mind, certainly persist. Australians are not a militaristic people, but they seem to take an ever-increasing pride in their military traditions. The Gallipoli campaign, as commemorated on Anzac Day, appears to have become the defining icon of our national identity. Federation certainly cannot compete with it, nor can the events of the Eureka Stockade of 3 December 1854, which was a brief and local affair. Historically speaking, Australia is a bit short on drama: no Declaration of Independence and no civil war. For a time after the Vietnam War, the armed forces were unpopular, but that does not seem to me likely to be duplicated after Iraq. We have apparently perfected a technique of sending only very small, highly professional forces that, thankfully, do not incur many casualties but do Australia credit in 'niche roles' 
with much larger allied forces. I think, therefore, that, on the whole, the tradition of the expeditionary force will persist, and the US alliance will continue to be regarded as a useful insurance policy, which enhances our security and our diplomatic clout at a rather low cost.

In retrospect, strategic debate in Australia can be seen to have focused closely on security preoccupations and sometimes allayed them. For the first five years of the nuclear age, the 'shock and awe' factor kept preoccupations chiefly on nuclear risk. The first task I was given in the Department of External Affairs was to write an analysis of the implications for Australia of the Baruch Plan, the first US effort at the UN to put the nuclear genie (which had been released in 1945) back in its bottle. I reported that there were no implications for Australia, because the Russians were going to kill the plan stone dead in the United Nations Security Council (UNSC), being determined to get nuclear weapons of their own. Unfortunately that turned out to be true. Ever since, my own work has focused on the relationship between strategy and diplomacy, and the way each is the context for the other. The Korean War (1950-53) had the strategic result of (as was said at the time) 'putting teeth into NATO'; in effect turning it from a diplomatic alliance into a forward-deployed military coalition. Surprising at first sight, but actually logical. Even before the assumption was confirmed in the last decade or so by the release in Moscow of the old Soviet archives, it was easy to see the diplomatic advantage to the Soviet Union of averting any rapprochement between the United States and China. In effect, it delayed détente for 20 years, until the Kissinger visit of 1971, and those were years when Moscow did pretty well in the Third World, whilst NATO built up its strength in Europe.

For Australia, however, late 1951 saw the development of what was proved (in retrospect) to be the 'foundation debate' of our foreign policy, whose outcome has governed our diplomatic choices for the whole 55 years since. It was the moment of choice of the US alliance as our 'guiding star' in the larger issues of external relations - those that bear on global conflicts, as against regional relationships with the small sovereignties of our immediate neighbourhood. The balance between those two commitments is the subject of much argument at the moment, and those arguments are likely to continue. No prime minister since Menzies' time has deviated from attachment to the US alliance, though Gough Whitlam in 1973-74 seemed for a while as if 
he might, and that appears to have been the only moment when the alliance was in some doubt in Washington, though if Mark Latham had made it to prime minister there might possibly have been another.

To revert for a moment to 1951, Spender ought, for good or ill, to be seen as the 'founding father' of the alliance instead of Menzies, who remained sceptical about the whole idea until it was up and running. At the beginning, he was reported to have said: 'Percy is trying to build a castle on a foundation of jelly.' However, the most consistent reaction against the ANZUS Treaty came from those still intensely distrustful of Japan, and fearful that Washington's need for an ally in north-east Asia would lead to a rapid rebuilding of Japan's industrial strength and a resurgence of militarism there. It took a decade or more for the memory of Australian prisoners-of-war emerging from Japanese camps as walking skeletons to fade from Australian minds.

Involvement in the war in Korea did not create anything like the degree of resentment in Australia that Vietnam did 15 years later, perhaps because it was fought under a UN banner, there was a more direct conventional invasion, and it was much shorter. The most notable preVietnam occasion of anti-US fervour came in the early 1960s, over what was then called Dutch New Guinea (later Irian Jaya, and now Papua). When the Kennedy administration came to office in Washington, they swiftly made it clear that they were not going to back Australia's efforts (which dated from Evatt's time) to keep the disputed territory free of Indonesian sovereignty. Without that diplomatic backing, neither Dutch nor Australian efforts had any hope of prevailing, so there was a disgracefully bogus 'Act of Choice' under UN auspices, and the stage was set for the more recent embarrassments. Yet the chances of effective resistance then were, to my mind, non-existent: the Dutch could not fight there, nor ourselves, and the Kennedy administration (in between the mounting problems in Vietnam, the looming crisis in Cuba, and the general Cold War tensions with the Soviet Union) could not really be expected to spare much thought for an obscure corner of the South Pacific.

In retrospect, I think we drew the wrong lesson from the Cuban missile crisis. What it really demonstrated was that, faced with a potential nuclear brink, the great powers will draw back and pursue their hostilities another way. For the United States and the Soviet Union, that meant, for the most part, a continued Cold War; but for lesser 
powers, or non-state actors, it seems probable that now it will tend to be asymmetric war governed by, more often than not, urban guerilla tactics. However, those concepts have only begun to be developed since 2001, and US Secretary of Defense Donald Rumsfeld apparently did not take much note of them when he sent US troops into Iraq.

The early 1960s were, however, in other ways almost as anxious a period in policymaking circles in Canberra as early 1942. Conditions were clearly deteriorating in Vietnam for its government in Saigon, and there was widespread uncertainty as to whether the United States would venture into combat involvement there, and even idle talk about the use of nuclear weapons. At the same time, the situation in Indonesia seemed to be advancing towards a coup, either by the generals or the communists. President Sukarno had embarked on his Konfrontasi with Malaysia, and consequently was waging a sporadic guerilla war against the British, who were asking for military and diplomatic assistance from Australia. (Our diplomats in Jakarta managed that crisis adroitly.) China, in Mao Tse-tung's disastrous final years in power, was evincing a spasm of revolutionary fervour, and cultivating the Indonesian communist party with particular zeal.

This period can therefore be seen as the first intimation of what I think is going to remain the characteristic dilemma of Australian policymakers in the fields of foreign policy and defence: how to hold the balance between Australia's regional commitments and anxieties and its global ones. Until the end of the colonial world, after World War II, international politics for three centuries revolved around Europe, with Japan and its Asian ambitions making a late entry in the 1930s, whilst the rest of the Third World had hardly any impact. Australia's destiny was thus essentially shaped by global factors, like the two World Wars and the Great Depression. That time (which Asian historians have called the Vasco da Gama era) has passed, but not our involvement with the central balance powers and their relationships. So our strategic debates must take account of both sides of the balance, and sometimes that will make for difficult choices, for instance, as to the type of weaponry chosen and training undertaken.

The world will probably be more turbulent over the next 40 years than in the past 40. That is because a multipolar society of states (which will probably replace the present unipolar one within that timeframe) 
offers far more opportunities for international friction and crisis than either a bipolar one (as in the Cold War) or a unipolar one (as from 1992 to date).

Australia will be living with a 'company of giants'. Four mega-powers - the United States, the European Union, China and India - will dominate the centre stage of world politics, but there will be at least six other formidable powers whose interests and capabilities will have to be taken into consideration by strategists: Russia, Japan, Pakistan, Mexico, Brazil and Nigeria. World population will have risen towards 9 billion, as against 6 billion at present. China and India together will account for about 3 billion, the other Asians for another billion. ${ }^{4}$ So Australia will have about 4 billion neighbours - most of them still quite poor. The United States will run to about 400 million citizens, and still have the most formidable advanced military. The European Union will run to about 600 million, but its power will still be mostly economic rather than military. Among the increasing world numbers, there will be about 2 billion Muslims, a tiny fraction of whom may still be minded to jihad. At least eight governments, possibly 10, will have nuclear weapons. In the coming decades of 'energy insecurity', small powers in the Persian Gulf, Africa, Latin America or Central Asia will acquire more diplomatic clout through possession of oil-bearing real estate, or offshore resources.

It is not only population numbers that need to be taken into account when assessing prospective pressures on resources and the environment; it is the 'revolution of rising expectations' - the determination of the governments and peoples of the poor world to live more like the rich world. With its present rate of economic growth (sometimes 10 per cent a year), China could relatively soon overtake the United States as the largest economy in the world. India might be its closest competitor a little later, for assorted demographic and political or social reasons. As countries grow more affluent, their demand for resources grows exponentially; so, for example, world demand for oil might quadruple as populations grow by 50 per cent. Moreover, supply of that commodity will become far more expensive as less available sources, like tar sands, have to be developed. The $\$ 100$ barrel of oil is already on the cards. Unless there is a technological

4 United Nations, Population Division: Forecasts to End of Century: ESA/P/WP (Department of Economics and Social Affairs, 2003), p. 187. 
revolution in the supply of energy, the old conflict between the 'haves' and the 'have-nots' could be re-created on a vastly larger scale than in the 1930s. For the next decade or so, our security preoccupations will no doubt remain focused on 'non-state actors' and their capacity for terrorist operations. In time, however, the traditional anxieties about the great powers (new or old) and their possible ambitions will be back, and the only feasible remedy for those anxieties will be diplomatic strategies and institutions.

All in all, one has to see the rest of this century as a time when Australia will be dealing with more complex diplomatic and strategic problems than it has faced in the past. It is still likely to feel the need for a 'great and powerful friend'. An unnecessary crisis with China is the only occasion that I can see as having alliance-breaking potential, as far as the United States is concerned, and I think that signal has probably already been conveyed to Washington. On a more hopeful note, however, one could also say that the transition to a multipolar world might expand the range of choice. We might aspire to friends, rather than a single friend, and to a multilateral alliance structure rather than a bilateral one. India will be a new power in Asia, whilst Japan will be an old one revived. Their interests will perhaps run parallel to those of Australia. There is no doubt that we will need resourceful diplomatists and strategists in Canberra for this more complex world.

As World War II approached, the Australian prime minister of the time, Joseph Lyons, spoke plaintively about a 'Pacific Pact'. It was not contemplated in any depth at the time, and has not really been since, if one takes the term to mean a truly comprehensive Asia-Pacific security community. In the more numerous, more powerful, and more interconnected group of sovereignties that will emerge in this region over the next 40 years, however, such a 'pact' might again be under consideration. All the powers will have more to lose than ever before. With luck, SDSC may still be around to help untangle their problems. 
This text is taken from A National Asset: 50 Years of the Strategic and Defence Studies Centre, edited by Desmond Ball and Andrew Carr, published 2016 by ANU Press, The Australian National University,

Canberra, Australia. 